\title{
Exploring factors influencing on organizational repurchases intention in B2B tourism context
}

\author{
Tung Tran Anha , Chau Tran Ngoc Diem ${ }^{b}$, Linh Nguyen Tran Cam ${ }^{\mathrm{c}}$ and Thuy Nguyen Viet ${ }^{\mathrm{d}^{*}}$
}

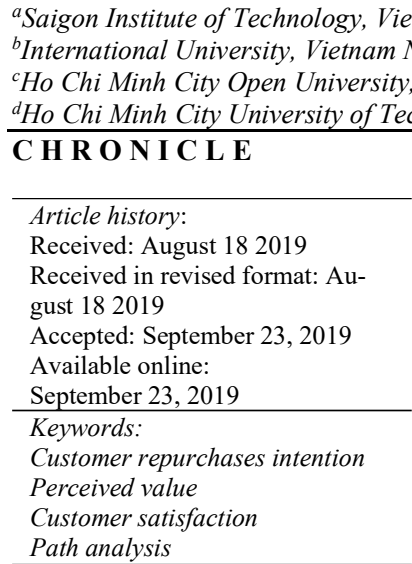

${ }^{b}$ International University, Vietnam National University, Ho Chi Minh City, Vietnam

vietnam

${ }^{d}$ Ho Chi Minh City University of Technology (HUTECH), Vietnam

\begin{tabular}{l} 
Article history: \\
Received: August 182019 \\
Received in revised format: Au- \\
gust 182019 \\
Accepted: September 23, 2019 \\
Available online: \\
September 23, 2019 \\
\hline Keywords: \\
Customer repurchases intention \\
Perceived value \\
Customer satisfaction \\
Path analysis
\end{tabular}

\section{A B S T R A C T}

\begin{abstract}
The relationship between perceived values; customer satisfaction and customer repurchase intention of organizations toward tour choice in Ho Chi Minh City (HCMC) was defined in this study. In addition, this study also identified the impacts of the five independent variables of tangibles, assurance, empathy, reliability and responsiveness and the intervening variables of perceived value and customer satisfaction on repurchase intention. Quantitative research was conducted by questionnaire with 300 middle and small organizations in HCMC, with variety of statistical techniques; including factor analysis, multiple regression analyses and path analysis to find the relationship between independent and dependent variables. Based on the results, the study suggests the fact that a higher perceived value would lead to a higher customer satisfaction. When consumers feel satisfied with services, they feel the choice was correct, which increases the customer's confidence and intention to repurchase the service in future.
\end{abstract}

(C) 2020 by the authors; licensee Growing Science, Canada

\section{Introduction}

Tourism is an important industry in Vietnam. Vietnam used to be an agrarian country, but now, it has transformed into a service economy. Nowadays, around 33\% of gross domestic product is created by services, which include the hotel, catering and transportation industries. Besides, other industries contribute smaller shares which are the manufacturing and construction (around 28\%) agriculture and fisheries (around 20\%) and mining (around 10\%). Meanwhile, travel contributes $4.5 \%$ in gross domestic product (year 2007). There is a growing rate of foreign domestic investment (FDI) projects poured into tourism. After heavy industries and urban development, foreign investors have focused on tourism industry, particularly in the hotel projects. With big potential, since 2001, tourism industry in Vietnam has been expanded by the government to be the leader in the national economic. Moreover, visitor arrivals in Vietnam have continued to increase in recent years. In 2008, Vietnam faced with 4.218 million worldwide travelers but in 2009 the number was 3.8 million, down 11\%. In 2012, Vietnam had 6.84 million visitors. This might have been a 13\% increase from 2011 which is about 6 million international visitors, and also was raised around 2 million visitors related to 2010 figure. In 2014, Vietnam was the host for more than 7.8 million international tourists, which is an increase of 2.1 million compared with arrivals in the year 2000. It means that tourism was a big potential industry and created many opportunities for businesses. In recent years, there have been more and more company organizes' tour for their customers and employees. In fact, some companies in Ho Chi Minh City have organized around $1-5$ tours for internal staff and external customers per year. For example, Holcim Vietnam Ltd. has organized 2 tours for bid distributors, around 20 tours for small retailers and from 5 to 10 tours for internal staffs in year 2015. Besides, Keycom Communication has provided 2 tours for internal staff in year 2014 and year 2015. Some other companies like People Link Ltd. Saigon Wedding Co. have organized at least one tour per year for internal staff. While Vietnam Tourism Industry is huge and there are

* Corresponding author.

E-mail address: nv.thuy@hutech.edu.vn (T. Nguyen Viet) 
many tour companies available. In the list of big tourist agency, we can easily learn about some names such as Vietravel, Saigon Tourist, Ben Thanh Tourist, Fiditour, Du Lich Viet, etc. Some other smaller companies such as Lua Viet Tour, Sac Viet Tour, Viet Tour, TST Travel Company are also developing such services. Therefore, there is a need to determine and comprehend the factors affecting the repurchase intention towards tour choice which would help in offering distinguish services to the consumers. In the tourism industry, group travel was known to be the main issue, and travel vendors have normally played a critical role in providing packaged services to potential tourist's time by time (Klenosky \& Gitelson 1998; Tepeci, 1999; Jin et al., 2012). Nowadays, there is a huge competition in the travel industry and it is crucial for researchers to learn more about the factors affecting the construction of tourists' intentions to repurchase a tour from a travel agency. Although there has been abundant evidence in the literature review that perceived value, service quality, and customer satisfaction all contribute important roles in defining tourists repurchase intentions; disagreements remain as temporary factors that are the most striking that influence repurchase intentions. The current research, employing nominal historical data, gives a good chance to reconsider the relationship in the tourism industry. It contributes to the existing literature in three ways.

- Firstly, it states that any increase in perception of service quality and perceived value leads to a higher customer's satisfaction, in turn increasing in tourists' intentions for future repurchase.

- Secondly, perceived service quality and perceived value are significant antecedents of customer repurchase intentions; direct links as well as indirect links via customer satisfaction between these two variables and repurchase intentions are supported in this research.

- Thirdly, in terms of service quality, while assurance, tangible and reliability just affect repurchase intention via perceived value and customer satisfaction, empathy may have direct effect to the customer repurchase intention.

\section{Literature Review}

\subsection{Customer Repurchase Intention}

Repurchase intention (RI) is determined as the individual's judgment about obtaining a service one more from the first time (Zeithaml et al., 1996). We argue that repurchase intention is one of the most important dependent variables in any system of relationships designed to establish management understanding and enhanced strategic planning and service delivery. Some scientists see an individual's goal to repurchase as one aspect of attitude (Zeithaml et al., 1996). Others stated that it was something different from attitude, for example, as a specific type of volition that changes the state of mind into real reactions (Bagozzi et al., 1989; Soderlund et al., 2001). Behavioral intentions were intermediated by the effect of both attitudes and normative factors on behavior which was proposed by some social analysts (Ajzen \& Fishbein, 1975). For this reason, the managers see a trend to identify how an individual's intention to repurchase is created abstractly and what factors affect that process in realistic.

There are many theoretical frameworks and empirical evidence in both the tourism industry and business literature showed that perceived quality, perceived value, and customer satisfaction are different factors which lead to repurchase intentions (Taylor \& Baker, 1994; Zeithaml, 1988). The comprehensive arguments and evidence on the relationship among these three factors and repurchase intentions are discussed in the following parts.

\subsection{Factors that affect Customer Repurchase Intention}

\subsubsection{Service Quality}

Service quality is generally inferred to the attitudes relevant to outstanding nature of a service (Li \& Song, 2011). Assessing the quality of service is a critical input for the customer decision process (Zeithml, 1988; Dodds et al., 1991). Service quality has long been playing a significant role in the competitive advantage of a company. We also focus on assessing the reflection of customer perceptions about specific dimensions of service: reliability, responsiveness, assurance, empathy, tangibles (SERVQUAL instrument, Parasuraman et al., 1988). Reliability is the ability to perform the guarantee service in a faithfully and accurately. Responsiveness is the preparedness and willingness of employees to help customers by providing efficiently timely services. Assurance is the knowledge and sympathy of employees and their ability to bring trust and confidence. Tangible is the presence of physical facilities, equipment, personnel and communication materials. Empathy is to provide care and attention to each customer. Another study shows that it is the extras or peripheral services leading to perceived value (Anderson \& Narus, 1995).

\subsubsection{Perceived value}

Perceived value is the process to evaluate its usefulness of a service based on the perception of received and given (Zeithaml, 1988). A basic framework for the conceptualization of perceived value was first proposed by Dodds and Monroe (1985) and further developed by Zeithaml (1988). Like suggested by Zeithaml, customers have many different views in evaluating value. For example, low-cost is valuable for some customers but not others. While value different definitions of all deserve, the majority of literature focused on the most basic version, which is "value is what consumers get when they give" (Zeithaml, 1988). In particular, perceived value for a product or service apprehends the quality received corresponding to the price acquired (Zeithaml Holbrook 1994) and customers usually take prices and quality into account when they hit the value (Chan et al., 2003). 


\subsubsection{Customer Satisfaction}

They believe that customer satisfaction is closely linked to the attitude which is expected to predict repurchase intention (Anderson \& Mittal, 2000; Reichheld, 1996; Anderson et al., 1994; Fornell, 1992). Therefore, customer satisfaction is a valuable outcome of excellent marketing field (Malthouse et al., 2004). Analytically, strong positive association between customer satisfactions and repurchase intentions in the context of both consumer's goods and services has been found by many researchers in the marketing field (Taylor \& Baker, 1994). In a list of critical studies on the development of national or regional customer satisfaction indexes, satisfaction has been found to be the most essential construct directly leading to customer loyalty, which covers different dimensions such as customer repurchase intentions, word of mouth, and price increase tolerance (Anderson et al., 1994).

\section{3. relationship among customer repurchase intention and nominated effect factors}

\subsection{1. relationship between service quality and perceived value}

When external services are proposed to distinguish one service from a competitive service by creating value (Anderson \& Narus, 1995), it is expected that a positive relationship exists between quality of the services of external services and perceived value, positive emotional evaluation results from cognitive value (Liljander \& Mattsson, 2002). Consumers' measure expected performance of the core service or product cores for the actual product or service they received and decide how their value has been received. The high level of quality is found to be the premise of the high level of perceived value. This leads to the following hypothesis:

$\mathrm{H}_{1}$ : Reliability influences positively on perceived value.

$\mathrm{H}_{2}$ : Responsiveness influences positively on perceived value.

$\mathrm{H}_{3}$ : There is a significant effect of assurance on perceived value.

$\mathrm{H}_{4}$ : There is significant effect of empathy on perceived value.

$\mathrm{H}_{5}$ : There is significant effect of tangibles on perceived value.

\subsection{2. relationship between perceived value and customer satisfaction}

Many researchers have found that perceived value may have a direct and encounter-specific relationship with customer satisfaction (Zeithaml et al., 1988; Sheils \& Sweeney, 1999). Brady and Robertson (2001) stated that repurchase intention was associated with consumer satisfaction. Komori and Bolton (1991) showed that such relationships exist because of the impact of specific trading customer satisfaction on service quality. This study supports the role of customer satisfaction as the mediator of perceived value and intent to repeat purchase and customers embraces the strong experimental evidence for customer satisfaction of perceived value and repurchase intention relationship. Therefore, in this study, we propose the following:

$\mathrm{H}_{6}$ : There is a significant effect from perceived value on customer satisfaction.

\subsection{3. relationship between customer satisfaction and repurchase intention}

In the marketing services literature, many studies have stated satisfaction is a key factor of repurchase intentions (Zeithaml et al., 1996). In tourism industry, the relationship between satisfaction and repurchase intention has also been widely proved in variety areas as cruises golfing island tourism heritage tourism rural tourism restaurants and lodging (Lee et al., 2004; Prayag \& Ryan, 2012; Chen \& Tsai, 2007; Su \& Hsu, 2013; Loureiro \& Kastenholz, 2011; Liu \& Jang, 2009; Malhotra et al., 2009). Based on the previous results, the below hypothesis is proposed:

$\mathrm{H}_{7}$ : There is a significant effect of customer satisfaction value on customer repurchase intention.

\subsubsection{The direct and indirect relationship among customer repurchase intention and nominated factors}

The mixed findings of service quality research determined the direct and indirect effects of service quality to customer satisfaction and repurchase intention. Both these pathways are then critical in inclusive modeling and are included here for testing the result. The service quality construct requires greater attention of content components (such as core and supplementary dimensions) and measurement to ensure adequate testing of customer requirements, service-oriented provider in a service context (Brady \& Robertson, 2001). We proposed that:

$\mathrm{H}_{8}$ : There are the direct and indirect effect of independent variables (reliability, responsiveness, assurance, empathy and tangible) on customer satisfaction.

There used to be arguments on the casual relationship between perceived service quality and consumer satisfaction (Cronin \& Taylor 1992; Bitner \&Hubbert 1994). One institute develops a thought that quality perception is a constant attitude and includes the current level of satisfaction (Parasuraman et al., 1988); therefore, service quality has to be seen as a superintend construct under whereby customer satisfaction is a component. In contrast, Cronin and Taylor (1992), stated that satisfaction 
is the superintend construct and quality is a component of the process composing the satisfaction intuition. As mentioned by Ekinci and Riley (1998), the arguments focus on separation of quality products from the satisfaction of inexorably related to the concept of satisfaction. Nowadays, researchers in marketing have services to the general advanced congruence on the basis of the difference between quality and satisfaction, where the satisfaction is relevant to the response reflects an emotional state of our clients of mind is made when they are exposed to an experience, while perceived quality service is an evaluation of attributes of a service which is mainly controlled by a provider (Baker \& Crompton 2000). So, quality should be an antecedent of customer satisfaction (Anderson et al., 1994).

In the field of tourism industry, Ekinci (2003) also claim that quality as one antecedent of customer satisfaction, which is linked between service quality and the intention of behavior. Service quality consciousness is discovered as affecting the intention to repurchase intention in a number of studies, such as Baker et al. (2002), Lee et al. (2004). However, it is still a confusion about whether service quality has directly or indirectly associated with repurchase intention variables via some intermediated variable such as customer satisfaction. For example, Baker and Crompton (2000) investigated the relationship between quality and satisfaction in a festival context and found that the awareness of high-quality service not only strengthen customer satisfaction but also encourages increased re-visitation from positive worth of mouth. Other studies, recognizing the impact of the quality of the service on the repurchase intention stated that satisfaction is an intermediate variable between service quality and repurchase intention (Ekinci, 2003). Thus, in this study, we will find out:

$\mathrm{H}_{9}$ : There are direct and indirect effects of independent variables (reliability, responsiveness, assurance, empathy and tangible) on customer repurchases intention.

Zeithaml (1988) further showed that perceived quality which leads to perceived value and purchase intentions. Bojanict (1996) suggested that perceived value is one of the most arresting elements of intent on buying and repeat visit. Zeithaml (1988) also reported that perceived value in hotel industry had a positive association with re-visitation. While a direct link between perceived service value and repurchase intentions is found to be significant, Ekinci et al. (2003) debated that influence of service value on repurchase intentions was mediated via satisfaction; that is, satisfaction is a partial mediator in the service value and repurchase intentions link. Thus, the following hypothesis was proposed in the study:

$\mathrm{H}_{10}$ : There are direct and indirect effects of perceived value on customer repurchases intention.

\subsection{Conceptual Framework}

Jin et al. (2012) contributed to the existing literature in three ways. First, it confirms that a higher perception of quality of service and value could contribute to a higher level of satisfaction of tourists, thus increasing traveler intentions for future patronage interest. Second, although the perceived quality of service and value is well known premise of intent to repurchase, a direct link between these two variables and repurchase intentions are not supported in this study. Instead, the link indirectly through satisfaction was found to be significant, which has always been supported by all the 9 years of survey data. Perceptions of service quality and perception of value is a measure of tourist awareness of the services provided for a special travel package, while assess satisfaction is driven more emotions (Anderson et al., 1994). The findings from this study indicate that tourists' emotions are stricter measure than the reaction in shaping perceptions of tourists' intention to redeem in the future. Third, some previous studies have also considered the judgment visitors to compare the relative impact of service quality, value and satisfaction as a result of the next turn (Lee et al., 2003, 2007, 2013), which may be one reason may be inconsistent results were previously reported on indirect data links between quality of service and value are mediated by satisfaction. The simultaneous inspections of the relationship between the two variables is defined in the current research.

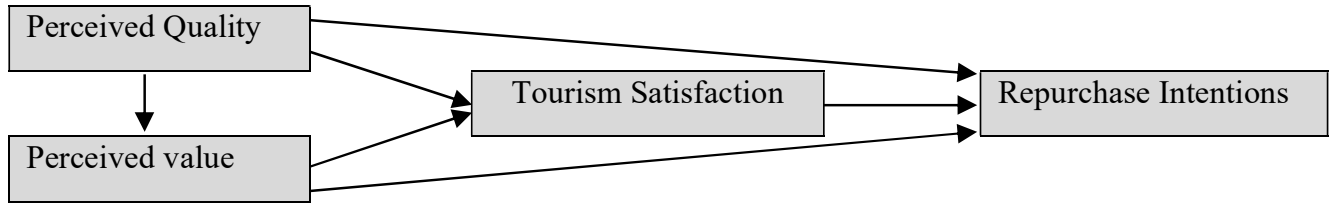

Fig. 1. Conceptual Framework of Jin et al. (2012)

Based on Jin et al. (2012) and as comprehensive examination of theories previously, we will be able to build a conceptual framework to determine different factors that affect customer repurchase intention toward tour choice which are service quality included reliability, responsiveness, assurance, empathy, tangibles and relationship between those factors with perceived value which leads to customer satisfaction and customers repurchase intention (See Fig. 2). 


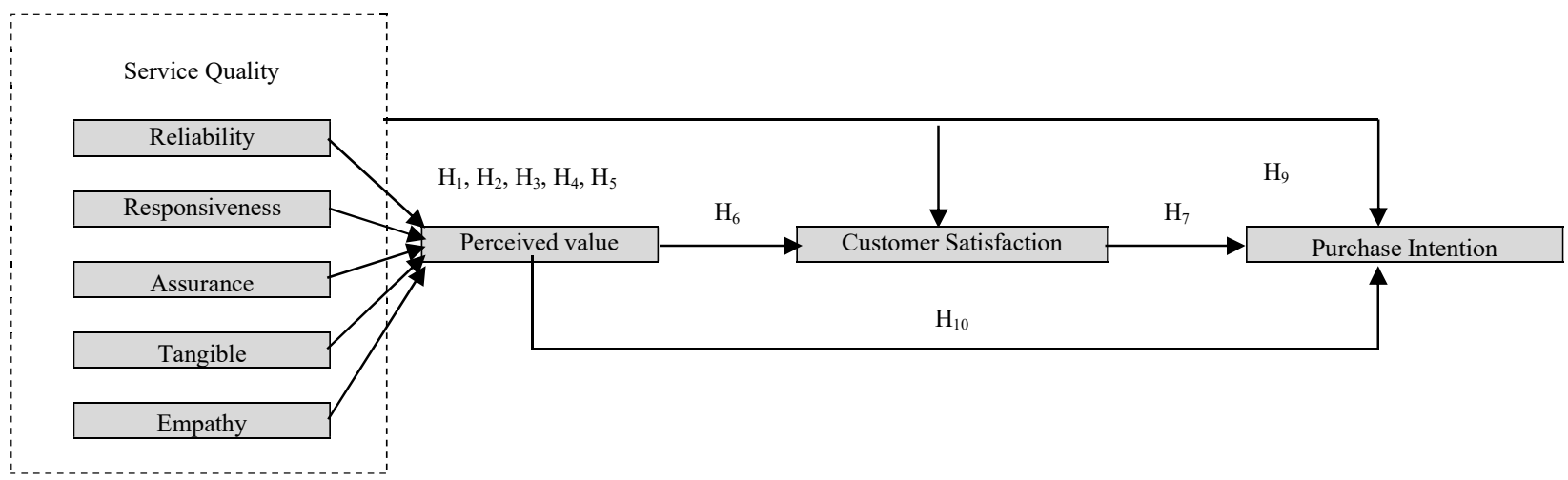

Fig. 2. Conceptual Framework

\section{Research methodology}

\subsection{Sample Determining}

Research sample quantity depends on methods of statistical analysis which is factor analysis exploring (EFA) used in this current study. To use EFA, the sample has to be large enough. Many previous studies stated that sample needed is usually equal to at least five times of variables in Exploratory Factor Analysis. The ratio of observation/ transform measuring in analyzing EFA is 5:1, which means that a measure minimum needs five observing. So, based on the number of variables observed in this study, the number of samples needed to analyze factors have to get at least 125. In addition, in this study, regression analysis was applied to test the hypothesis and models study. To achieve the best results in regression analysis, sample size has to satisfy the formula is $\mathrm{n} \geq 8 \mathrm{p}+50$, where $n$ is sample size and $p$ is the number of independent variables of the model. Thus, in this study, we needed to choose sample size big enough to satisfy both conditions: analysis factor EFA and regression analysis. The corresponding scale theory contains 25 independents and 15 dependent variables, number of samples minimum was:

$$
\mathrm{n}>=\max (25 \times 5 ; 8 \times 15+50)=170 \text { samples }
$$

So, the minimum sample size is 125 samples. Nevertheless, for the best result with variety samples, the study aimed to delivery question for 300 small and middle organizations in Ho Chi Minh City.

\subsection{Research instrument and data collection}

Questionnaire design was started first with the development of a solid theoretical framework. From secondary data, the theory was gathered and analyzed. After the theoretical basis already in hand, the questionnaire was set. The questions were accordingly raised to ensure the reliability and validity of all the size of the study. Most of the questions were built on a five-point Likert scale ranging 1-5, equivalent to strongly disagree, disagree, neutral, agree and strongly agree respectively. As the instrument of primary data collection, a structured questionnaire (i.e. questions that indicate the response plans and response formats (Malhotra et al., 2004; Gallarza et al., 2011), was used to collect qualitative data the amount required. By using selfmanaged surveys, respondents could answer the questions without any fear of the interviewer or administrator. Moreover, we were enabled to control the situation when answering the questions (Burns et al., 2000).

\subsection{Data analysis}

\subsubsection{Validity and Reliability test}

Cronbach's Alpha coefficient was used to assess the reliability of the scale. Nunnally and Bernstein (1994) stated that a scale was reliabile when it varies in the range [0.7-0.8], if the coefficient is greater than, 0.6 is acceptable scale. After checking the reliability of the measuring scale, factor analysis was conducted to explore the data. Extract method was chosen to be the factor analysis method of principal components with varimax rotation. A number of criteria that should interest researchers in Exploratory Factor Analysis (EFA) as (Pallant, 2005):

- $\quad$ Coefficient of KMO (Kaiser-Mayer-Olkin): $0.5 \leq \mathrm{KMO} \leq 1$ (Norusis, 1994).

- The level of significance of Bartlett $\leq 0.05$, meaning that the variables have relationships with each other.

- $\quad$ EFA model fit when the total variance extracted $\geq 50 \%$.

- $\quad$ Eigenvalue modification coefficient $\geq 1$ (Gerbing \& Anderson, 1998), i.e. the number of factors identified in the minimum eigenvalue modification factors equal to 1 . 
- Among the factors (Factor loading) of each observed variable $\geq 0.5$; however, some factors $\geq 0.4$ can also be accepted in the case of the observed variables measuring the content of important value. The difference between the weights of a variable factor observed between $\geq 0.3$ to create value to differentiate between them (Jabnoun \& Al-Tamimi, 2003).

\subsubsection{Regression analysis}

Multiple linear regressions were often used to test and explain the theory of causation. In addition to the function as described, a multiple linear regression was used as the conclusion to test the hypotheses and predictions of the value of the overall study. So, for this research, multiple linear regressions were the appropriate method to test the research hypotheses. When explaining the regression equation, the researchers have to focus on the multi-collinearity phenomenon. Many issues arise when multi-collinearity phenomenon exist, for example it could increase uncertainty in the calculated beta coefficient, regression coefficient generating marked contrast with what researchers expected and T-test results have no statistically significant while the F-test results for general model has statistical significance. Degree of acceptance (of Tolerance) and the variance inflation factor $(V I F)$ which quantifies how much the variance is inflated is usually used to measuring this phenomenon. If the VIF is larger than 10, the variables are strongly correlated. To avoid multi-collinearity phenomenon, the VIF have to be smaller than 10 .

Table 1

The measurement scale

\begin{tabular}{|c|c|c|}
\hline Variables & Description of statement & Coded \\
\hline \multirow{5}{*}{ Reliability } & When this company promises to do something by a certain time, it does so & RELI1 \\
\hline & When you have a problem, this company show a sincere interest in solving it & RELI2 \\
\hline & This company performs the service right the first time & RELI3 \\
\hline & This company provides its service at the time at promises to do so & RELI4 \\
\hline & The company has competitive prices & RELI5 \\
\hline \multirow{5}{*}{ Responsiveness } & Employees in this company give your prompt service & RESPO1 \\
\hline & Employees in this company are always willing to help you & RESPO2 \\
\hline & Employees in this company are always respond to your requests & RESPO3 \\
\hline & Employees in this company do not make customer wait long time & RESPO4 \\
\hline & Employees in this company solve problems quickly & RESPO5 \\
\hline \multirow{5}{*}{ Assurance } & The behavior of employees in this company instills reliable in you & ASSU1 \\
\hline & You feel safe in your transactions with this company & ASSU2 \\
\hline & Employees in this company are consistently courteous with you & ASSU3 \\
\hline & Employees in this company are well knowledge to perform their tasks properly & ASSU4 \\
\hline & Employees in this company have more experience to solve problems & ASSU5 \\
\hline \multirow{6}{*}{ Tangible } & This company has modern-looking equipment & TAGI1 \\
\hline & This company's physical facilities are visually appealing & TAGI2 \\
\hline & The company's employees are neat-appearing & TAGI3 \\
\hline & The company's office is very convenient & TAGI4 \\
\hline & The company has many kinds of payments & TAGI5 \\
\hline & The company has many impress advertisings and memorable & TAGI6 \\
\hline \multirow{5}{*}{ Empathy } & This company gives you individual attention & EMPA1 \\
\hline & This company has your best interests at heart & EMPA2 \\
\hline & Employees of this company understand your specific needs & EMPA3 \\
\hline & The company can serve clients outside working hours & EMPA4 \\
\hline & The company always priorities the benefits of customers & EMPA5 \\
\hline \multirow{5}{*}{ Perceive Value } & This company is a professional company & PERVA1 \\
\hline & We have positive thinking about this company & PERVA2 \\
\hline & We have many good experiences with this company & PERVA3 \\
\hline & Service quality of this tour equals to the fee you paid. & PERVA4 \\
\hline & Attributes of this tour equals to the fee you paid. & PERVA5 \\
\hline \multirow{7}{*}{ Customer satisfaction } & Satisfy with tour program & SATIS1 \\
\hline & Satisfy with customer service & SATIS2 \\
\hline & Satisfy with tour guide & SATIS3 \\
\hline & Satisfy with drink/food/accommodation of this tour & SATIS4 \\
\hline & Satisfy with company service & SATIS5 \\
\hline & Match with our expectation & SATIS6 \\
\hline & Chosen this company is a right decision & SATIS7 \\
\hline \multirow{5}{*}{ Repurchase Intention } & We are confident when choosing this tour company next time & REPUR1 \\
\hline & Choose this tour agents again in the future & REPUR2 \\
\hline & We will work with this company in next time & REPUR3 \\
\hline & We will recommend this tour company for others & REPUR4 \\
\hline & We will encourage others to use this tour & REPUR5 \\
\hline
\end{tabular}




\section{Findings}

\subsection{Descriptive statistic}

Regarding to company joining this survey, there are about $42 \%$ private company which is the largest sample of this study. Besides, foreign company stands in second position with $35 \%$ and lastly, the government company accounts for $23 \%$.

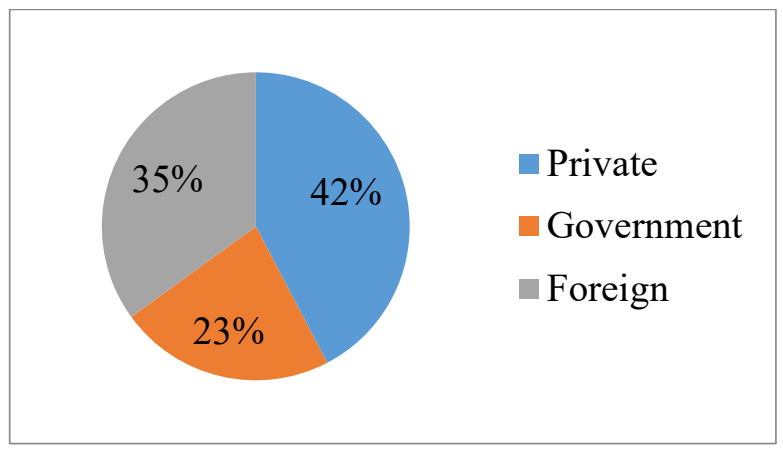

Fig. 3. Percentage of kind of company joining survey

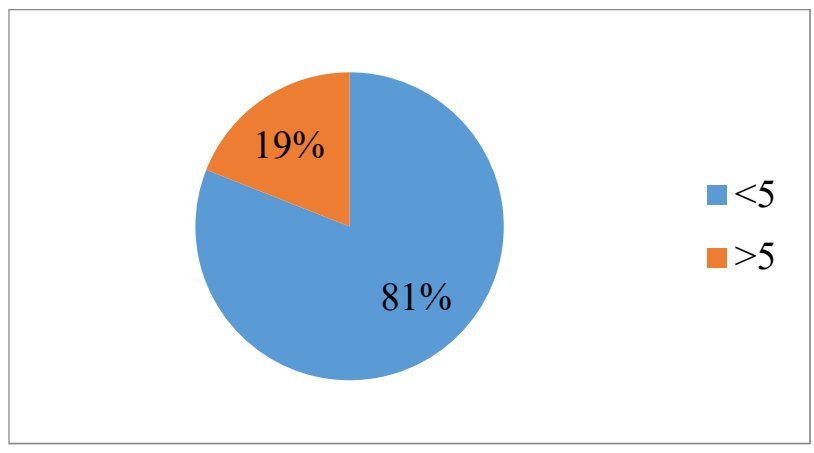

Fig. 4. How many tours your company organizes in one year?

About the quantity of tours that each company joining survey organized every year, about $81 \%$ of the companies had at least 1 from 5 tours per year and just about 19\% company had more than 5 tours per year.

\subsection{Reliability and Validity Test}

To evaluate the reliability, conversion and discriminant value, Cronbach's Alpha and Explore factor analysis techniques were performed. A good scale reliability is good when it varies in the range [0.7-0.8], however, if Cronbach's Alpha $>=0.6$, scale is acceptable in terms of reliability (Nunnally \& Berntein ,1994).

Table 2

Cronbach's Alpha coefficient

\begin{tabular}{llllll}
\multicolumn{1}{c}{ Variables } & Number of items & Cronbach's Alpha & Variables & Number of items & Cronbach's Alpha \\
\hline Responsiveness & 5 & 0.68 & Assurance & 5 & \\
Tangible & 3 & 0.68 & Perceive value & 5 & 0.616 \\
Empathy & 5 & 0.623 & Customer Satisfaction & 7 & 0.614 \\
Reliability & 2 & 0.697 & Repurchase Intention & 5 & 0.776 \\
\hline
\end{tabular}

Table 2 indicated all variables satisfied the given criteria of reliability.

Independent variables analysis

Next we came to the EFA stage, the result was that there were 5 components extracted, total variance extracted $=66.570 \%$, it showed that the five components explained $66.570 \%$ of the data variability. In addition, the indication of Kaiser - Meyer Olkin (KMO) was $0.749>0.6$, and the Bartlett's Test of Sphericity had Sig. $=0(<0.05)$, it signifies that there was the connection of five factors; they are suitable with the case of factor analysis. Therefore, the Exploratory Factor Analysis method seemed to be useful for this research.

With the final rotated round, thirteen items are gathered into five components shown in Table 3.

Table 3

Rotated Component Matrix

\begin{tabular}{|c|c|c|c|c|c|}
\hline & \multicolumn{5}{|c|}{ Component } \\
\hline & 1 & 2 & 3 & 4 & 5 \\
\hline RESPO3: Employees in this company are always respond to your requests & .818 & & & & \\
\hline RESPO5: Employees in this company solve problems quickly & .763 & & & & \\
\hline RESPO1: Employees in this company give your prompt service & .720 & & & & \\
\hline TAGI4: The company's office is very convenient & & .786 & & & \\
\hline TAGI6: The company has many impress advertisings and memorable & & .775 & & & \\
\hline TAGI2: This company’s physical facilities are visually appealing & & .716 & & & \\
\hline EMPA5: The company always priorities the benefits of customers & & & .774 & & \\
\hline EMPA1: This company gives you individual attention & & & .747 & & \\
\hline EMPA3: Employees of this company understand your specific needs & & & .731 & & \\
\hline RELI5: The company has competitive prices & & & & .847 & \\
\hline RELI3: This company performs the service right the first time & & & & .839 & \\
\hline ASSU1: The behavior of employees in this company instills reliable in you & & & & & .845 \\
\hline ASSU3: Employees in this company are consistently courteous with you & & & & & .796 \\
\hline $\mathrm{KMO}=.749$ & & & & & \\
\hline
\end{tabular}


Dependents variables analysis

There were 3 components extracted, total variance extracted $=62.096 \%$ and it showed that the three components explained $62.096 \%$ of the data variability. In addition, the indication of Kaiser - Meyer - Olkin (KMO) is $0.814>0.6$, and the Bartlett's Test of Sphericity had Sig. $=0(<0.05)$, it signifies that there was a connection of three factors

Table 4

$\underline{\text { Rotated Component Matrix }}{ }^{\mathrm{a}}$

\begin{tabular}{lc} 
& \multicolumn{1}{c}{ Component } \\
\cline { 2 - 2 } SATIS5: Satisfy with company service & .848 \\
SATIS3: Satisfy with tour guide & .757 \\
SATIS7: Chosen this company is a right decision & .744 \\
SATIS1: Satisfy with tour program & .622 \\
REPUR3: We will work with this company in next time & .849 \\
REPUR5: We will encourage others to use this tour & .724 \\
REPUR1: We are confident when choosing this tour company next time & .641 \\
PERVA3: We have many good experience with this company & .790 \\
PERVA5: Attributes of this tour equals to the fee you paid. & .748 \\
PERVA1: This company is an professional company & .635 \\
\hline KMO = .814 (Sig. $=.000)$ &
\end{tabular}

\subsection{Regression Analysis}

\subsubsection{Regression Analysis of Perceived Value Dimensions}

Table 5

Regression analysis results of Perceived Value

\begin{tabular}{|c|c|c|c|c|c|c|c|}
\hline \multirow{2}{*}{ Model } & \multicolumn{2}{|c|}{ Unstandardized Coefficients } & \multirow{2}{*}{$\begin{array}{c}\text { Standardized Coefficients } \\
\text { Beta }\end{array}$} & \multirow[b]{2}{*}{$\mathrm{t}$} & \multirow{2}{*}{ Sig. } & \multicolumn{2}{|c|}{ Collinearity Statistics } \\
\hline & $\mathrm{B}$ & Std. Error & & & & Tolerance & VIF \\
\hline (Constant) & 1.340 & .295 & & 4.542 & .000 & & \\
\hline RESPO: Responsiveness & .079 & .054 & .087 & 1.468 & .043 & .762 & 1.313 \\
\hline TAGI: Tangibles & .120 & .054 & .126 & 2.239 & .026 & .833 & 1.200 \\
\hline EMPA: Empathy & .135 & .057 & .132 & 2.384 & .018 & .872 & 1.147 \\
\hline RELI: Reliability & .133 & .044 & .170 & 3.028 & .003 & .846 & 1.181 \\
\hline ASSU: Assurance & .185 & .050 & .211 & 3.726 & .000 & .830 & 1.204 \\
\hline
\end{tabular}

According to the results of Table 5, the Standardized Coefficients $\beta$ between Perceived Value and Assurance, Empathy, Tangibles, Reliability was positive and significant when the level of significance is five percent. This demonstrated that Assurance, Empathy, Tangibles, Reliability were related to Perceived Value, or there was a linear relationship between Perceived Value and Assurance, Empathy, Tangibles, Reliability. In addition, for measuring how strong is the impact level between Perceived Value and Assurance, Empathy, Tangibles, Reliability, we continue with the Standardized Coefficients $\beta$ in table above. The largest value of the Standardized Coefficients $\beta$ is 0.185 ; which means that Assurance dimension has maintained the strongest impact to Perceive value. The Standardized Coefficients $\beta$ of Empathy and Reliability are 0.133 and 0.135 , respectively. The smallest value of the Standardized Coefficients $\beta$ is 0.120 ; which means that Tangible dimension has had the lowest impact to Perceived value.

\subsubsection{Regression Analysis of Customer Satisfaction Dimensions}

Table 6

Regression analysis results of Customer Satisfaction

\begin{tabular}{|c|c|c|c|c|c|c|c|}
\hline \multirow{2}{*}{ Model } & \multicolumn{2}{|c|}{ Unstandardized Coefficients } & \multirow{2}{*}{$\frac{\text { Standardized Coefficients }}{\text { Beta }}$} & \multirow{2}{*}{$\mathrm{t}$} & \multirow{2}{*}{ Sig. } & \multicolumn{2}{|c|}{ Collinearity Statistics } \\
\hline & $\mathrm{B}$ & Std. Error & & & & Tolerance & VIF \\
\hline (Constant) & 1.065 & .289 & & 3.679 & .000 & & \\
\hline RESPO: Responsiveness & .071 & .051 & .081 & 1.400 & .163 & .756 & 1.323 \\
\hline TAGI: Tangibles & .082 & .051 & .088 & 1.588 & .113 & .819 & 1.221 \\
\hline 1 EMPA: Empathy & .103 & .054 & .102 & 1.894 & .059 & .855 & 1.169 \\
\hline RELI: Reliability & .041 & .042 & .053 & .969 & .333 & .821 & 1.218 \\
\hline ASSU: Assurance & .129 & .048 & .151 & 2.693 & .007 & .793 & 1.261 \\
\hline PERVA: Perceived Value & .289 & .055 & .295 & 5.220 & .000 & .781 & 1.280 \\
\hline
\end{tabular}

According to Table 6, the Standardized Coefficients $\beta$ between Customer Satisfaction and Assurance, Perceived Value was positive and significant when the level of significance is 5 percent. This demonstrated that Assurance and Perceived Value were associated with Customer Satisfaction, or there were linear relationships between Perceived Value and Assurance and Customer Satisfaction. The Standardized Coefficients $\beta$ of Assurance and Perceived Value are 0.129 and 0.289 , respectively. 


\subsection{Indirect, Direct, and Total Casual Effects}

According to Table 7, the results indicate the direct and indirect effect among nominated variables and customer repurchase intention as follows:

Table 7

Direct, Indirect, and Total Casual Effects

\begin{tabular}{lccc} 
& & Casual Effects & Total \\
\cline { 3 - 4 } \multicolumn{1}{c}{ Variables } & Direct & Indirect & 0.087 \\
\hline 1. ASSU & - & 0.087 & 0.039 \\
2. TAGI & - & 0.039 & 0.043 \\
3. RELI & - & 0.043 & 0.202 \\
4. EMPA & 0.167 & 0.035 & - \\
5. RESPO & - & - & 0.263 \\
6. PERVA & 0.263 & - & 0.214 \\
7. SATIS & 0.214 & - & 0.848 \\
\hline Total & 0.644 & 0.204 & \\
\hline
\end{tabular}

\subsubsection{Indirect and Direct Effects of the Customer Repurchase Intention}

\section{Perceived Value}

The results of multiple regression analysis show that the perceived value is associated with five important predictors: assurance $(\beta=.185, \mathrm{p}<.05)$, tangibles $(\beta=.120, \mathrm{p}<.05)$, empathy $(\beta=.135, \mathrm{p}<.05)$, reliability $(\beta=.0133, \mathrm{p}<.05)$ and responsiveness $(\beta=.0079, p>.1)$. Based on beta indicator and $p$ value, four out of these five factors directly affected the perceived value and then perceived value directly caused an effect on the customer repurchase intention with $(\beta=.263$, p $<.001)$. Therefore, through the intervening variable of perceived value, the factors of assurance, tangibles, reliability and empathy created indirect effects on the customer repurchase intention with (.048), (.031), (.035), and (.035), respectively. These findings indicated that the existence of assurance, tangibles, reliability and empathy had significant positive effects on perceived value and customer repurchases intention. Thus, this study argues that as assurance, tangibles, reliability and empathy are present in a greater amount, the perceived value and customer repurchase intention are likely to be greater.

\section{Customer Satisfaction}

The result of multiple regression analysis showed that the customer satisfaction significantly was related to four important predictors: responsiveness $(\beta=.071, \mathrm{p}>0.5)$, tangibles $(\beta=.082, \mathrm{p}>.05)$, empathy $(\beta=.103, \mathrm{p}>.05)$, reliability $(\beta=.041, \mathrm{p}$ $>.05)$, assurance $(\beta=.129, \mathrm{p}<.05)$, perceived value $(\beta=.289, \mathrm{p}<.001)$. Based on beta indicator and $\mathrm{p}$ value, two out of these six factors directly affected the customer satisfaction and then customer satisfaction directly caused an effect on the customer repurchase intention with $(\beta=.214, \mathrm{p}<.001)$. Therefore, through the intervening variable of customer satisfaction, the factors of assurance and perceived value created indirect effects on the customer repurchase intention at (.027) and (.06), respectively. These findings indicated that the existence of assurance and perceived value had significant positive effects on customer satisfaction and repurchase intention. Thus, this study argues the higher quality level of assurance and perceived value is, the greater the perceived service quality and customer satisfaction are.

\subsubsection{Direct effects of Customer repurchase intention}

In order to explore the direct effects of the independent and intervening variables on the customer repurchase intention, the result of multiple regression analyses show that the customer repurchase intention was directly affected by three factors: empathy $(\beta=.167, \mathrm{p}<.05)$, perceived value $(\beta=.214, \mathrm{p}<.05)$ and customer satisfaction $(\beta=.263, \mathrm{p}<.001)$.

\subsubsection{Total Causal Effects of the Customer Satisfaction}

Table 7 summarizes the effects of the independent variables (Assurance, Tangible, Reliability, Empathy and Responsiveness) together with Perceived value and Customer Satisfaction on the dependent variable (Repurchase Intention) of this study. Regarding the total effects, the Perceived value factor had the strongest effect on Repurchase Intention with $\beta=0.263$. Next is the Customer Satisfaction with $\beta=0.214$. The factor of Empathy was ranked at third with $\beta=0.202$. This means that Assurance, Tangible, and Reliability had a low effect on the Repurchase Intention. The total effect of these factors on Repurchase Intention was 0.169 . Regarding the direct effects, the Perceived value had the strongest impact of the Customer repurchase Intention with $\beta=0.263$. Next is the factor of Customer Satisfaction with $\beta=0.214$, and lastly, the Empathy features with $\beta=0.167$. The total of direct effects of all these independent and dependent variables on the main dependent variable of the study was 0.644 . Regarding the indirect effects, the Assurance had the strongest indirect effect on the customer repurchase intention with $\beta=0.087$, followed by the Reliability with $\beta=0.043$, next by Tangible with $\beta=0.039$. The last factor was Empathy features with $\beta=0.035$. The total indirect effect of the independent variables on the Customer Satisfaction was 0.204 . 


\subsection{Hypotheses Summary}

The following summarizes the results of our investigation.

\begin{tabular}{|c|c|}
\hline Hypotheses & Significant effect \\
\hline H1: There is a significant effect of reliability on perceived value & No supported \\
\hline $\mathrm{H} 2$ : There is a significant effect of responsiveness on perceived value & No supported \\
\hline H3: There is a significant effect of assurance on perceived value & No supported \\
\hline H4: There is significant effect of empathy on perceived value & Supported \\
\hline H5: There is significant effect of tangibles on perceived value & No supported \\
\hline H6: There is a significant effect of perceived value on customer satisfaction & Supported \\
\hline H7: There is a significant effect of customer satisfaction value on customer repurchase intention & Supported \\
\hline $\begin{array}{l}\text { H8: There are the direct and indirect effect of independent variables (reliability, responsiveness, assurance, empathy and } \\
\text { tangible) on customer satisfaction. }\end{array}$ & Partially Supported \\
\hline $\begin{array}{l}\text { H9: There are the direct and indirect effect of independent variables (reliability, responsiveness, assurance, empathy and } \\
\text { tangible) on customer repurchases intention. }\end{array}$ & Partially Supported \\
\hline H10: There are the direct and indirect effect of perceived value on customer repurchases intention. & Partially Supported \\
\hline
\end{tabular}

\section{Conclusion and Recommendation}

\subsection{Conclusion}

The study has been succeeded to examine different hypotheses of the survey. The direct and indirect effects of the customer repurchase intention were argued and interpreted to get a clear answer and obvious proof to the entire research hypotheses. Explanations and recommendations are given depending on the literature review and the empirical findings of the research. The application of this study provides both theoretical and practical contributions to customer relationship management field. The results of this study stated that not all factors have direct and indirect effects on the customer repurchase intention. Future research should apply the model in other contexts with more meaningful statements for each variable or elements of the customer repurchase intention.

\subsection{Recommendation}

Perceived value is important for consumers. An increase in reliability leads to a higher perceived value of consumers. This is a useful tactic for companies to gain better favor of their consumers. One of the ways to have a higher reliability in consumer perception is to focus on consumer services. Based on this research, it is very important that a company keeps her promises made to her consumers. Hence, the company should have good training courses for staffs to let them understand what they can communicate and what they should not do to consumers, to avoid any unwanted expectation from consumers. In addition, the company should sincerely spend time and effort to understand an issue of consumers and must be willing to solve a problem on time. Particularly, a meeting among related departments can be held to understand the root cause of the problems. This would help to improve the current system and to avoid the issue happening to our clients again.

The finding in this research also showed that responsiveness does not have a significant impact on perceived value. This would help to let a company know where they should put their focus and investment on. Regarding customer service, the speed in responsiveness might not be crucial to consumers. Hence it is important to guide the company focus on quality than on speed. For example, if a consumer approaches with a concern, the staff should spend time to find the most accurate information for a consumer rather than provide a quick but untrusted answer. On the other hand, if a consumer has many requests that the company could not satisfy them all, the travel agency can focus on providing best solutions to some of the request, and give proper reasons for the left that they could not response.

Contrary to responsiveness, assurance is highly positively related to perceived value. A company should let consumer have peace of mind when they are using the services. The expertise level of staffs definitely plays a key role in this case. The company should provide good courses to let them understand clearly about pros and cons of the products, the most updated news in the industry, and common concerns of the target consumers. Hence, anytime consumers approach them, the staffs are ready to provide appropriate and accurate information. Also, the other way to convince consumers about our assurance might be a detailed contract with terms that can protect both of parties in the unfavorable condition. In this case, consumers definitely have a higher confidence in the transaction since they know they are secured by the commitment of the company. Besides the assurance and reliability, tangible assets are also shaping perceived values of consumers towards a company. The company should invest on appearance of their office, particularly whether employees are neat and professional, or whether physical facilities are visually appealing. Importantly, awards and certificates would definitely play a key role in convincing consumers about the quality of the product. Moreover, a wide range of payment methods also make a good impression on consumers. Paying attention to customers' requirement and prioritizing their benefits would enhance competitive advantage of the company. A corporate consumer needs a company to understand their specific needs and provide the right solutions and services to them. For example, if the consumer is in different time zone, they look for a company who can serve them outside of the working hours in the country that provides services.

The above operation and marketing activities are recommended in order to serve one main purpose, which is a higher perceived value of consumers. It is due to the fact that a higher perceived value would lead to a higher customer satisfaction. When consumers feel satisfied with services, they would feel the choice that they have made is right. This would affirm their 
confidence and intention to repurchase the service in the next time. So, to attract and retain tourists, travel agents should be essentially oriented quality and maintain a passable level of service quality. However, a mind-set quality may not be enough in a business environment competitive. A mind set of quality management oriented intensive focus on the internal processes of a company. To become a competitive player in the market, however, a travel agent needs to be more customers focused. For this purpose, emphasis on quality improvement should be extended to customer satisfaction because satisfaction is a prerequisite immediately affected more than the intentions of tourists to buy back. In other words, design and provide excellent quality of service is not the ultimate goal of a service company. Instead, businesses need to be able to be aware about improving customer quality. Thus, a higher priority should be given by the travel agent to enhance the satisfaction of tourists.

\section{References}

Ajzen, I., \& Fishbein, M. (1977). Attitude-behavior relations: A theoretical analysis and review of empirical research. Psychological Bulletin, 84(5), 888.

Anderson, E. W., \& Mittal, V. (2000). Strengthening the satisfaction-profit chain. Journal of Service research, 3(2), $107-120$.

Anderson, E. W., Fornell, C., \& Lehmann, D. R. (1994). Customer satisfaction, market share, and profitability: Findings from Sweden. Journal of Marketing, 58(3), 53-66.

Anderson, J. C., \& Narus, J. A. (1995). Capturing the value of supplementary services. Harvard Business Review, $73,75-83$.

Bagozzi, R. P., Baumgartner, J., \& Yi, Y. (1989). An investigation into the role of intentions as mediators of the attitudebehavior relationship. Journal of Economic Psychology, 10(1), 35-62.

Baker, D. A., \& Crompton, J. L. (2000). Quality, satisfaction and behavioral intentions. Annals of Tourism Research, 27(3), 785-804.

Bitner, M. J., \& Hubbert, A. R. (1994). Encounter satisfaction versus overall satisfaction versus quality. Service quality: New Directions in Theory and Practice, 34(2), 72-94.

Brady, M. K., \& Robertson, C. J. (2001). Searching for a consensus on the antecedent role of service quality and satisfaction: an exploratory cross-national study. Journal of Business Research, 51(1), 53-60.

Burns, A. C., Bush, R. F., \& Sinha, N. (2000). Marketing research (pp. 599-602). Upper Saddle River, NJ: Prentice Hall.

Chen, C. F., \& Tsai, D. (2007). How destination image and evaluative factors affect behavioral intentions?. Tourism Management, 28(4), 1115-1122.

Cronin Jr, J. J., \& Taylor, S. A. (1992). Measuring service quality: a reexamination and extension. Journal of marketing, 56(3), 55-68.

Dodds, W. B., \& Monroe, K. B. (1985). The effect of brand and price information on subjective product evaluations. ACR North American Advances.

Dodds, W. B., Monroe, K. B., \& Grewal, D. (1991). Effects of price, brand, and store information on buyers' product evaluations. Journal of Marketing Research, 28(3), 307-319.

Ekinci, Y., \& Riley, M. (1998). A critique of the issues and theoretical assumptions in service quality measurement in the lodging industry: time to move the goal-posts? International Journal of Hospitality Management, 17(4), 349-362.

Ekinci, Y., Prokopaki, P., \& Cobanoglu, C. (2003). Service quality in Cretan accommodations: marketing strategies for the UK holiday market. International Journal of Hospitality Management, 22(1), 47-66.

Fornell, C. (1992). A national customer satisfaction barometer: The Swedish experience. Journal of Marketing, 56(1), 6-21.

Gallarza, M. G., Gil-Saura, I., \& Holbrook, M. B. (2011). The value of value: Further excursions on the meaning and role of customer value. Journal of Consumer Behaviour, 10(4), 179-191.

Hu, L. T., \& Bentler, P. M. (1998). Fit indices in covariance structure modeling: Sensitivity to underparameterized model misspecification. Psychological Methods, 3(4), 424.

Jabnoun, N., \& Hassan Al-Tamimi, H. A. (2003). Measuring perceived service quality at UAE commercial banks. International Journal of Quality \& Reliability Management, 20(4), 458-472.

Jin, L., He, Y., \& Song, H. (2012). Service customization: To upgrade or to downgrade? An investigation of how option framing affects tourists' choice of package-tour services. Tourism Management, 33(2), 266-275.

Klenosky, D. B., \& Gitelson, R. E. (1998). Travel agents' destination recommendations. Annals of Tourism Research, 25(3), 661-674.

Komori, S., \& Bolton, T. B. (1991). Inositol trisphosphate releases stored calcium to block voltage-dependent calcium channels in single smooth muscle cells. Pflügers Archiv, 418(5), 437-441.

Lee, E. H., Kang, D. H., Lee, J. C., Kim, C. J., \& Lim, H. (2013). U.S. Patent No. 8,618,543. Washington, DC: U.S. Patent and Trademark Office.

Lee, N., Hui, D., Wu, A., Chan, P., Cameron, P., Joynt, G. M., ... \& Lui, S. F. (2003). A major outbreak of severe acute respiratory syndrome in Hong Kong. New England Journal of Medicine, 348(20), 1986-1994.

Lee, S. Y., Petrick, J. F., \& Crompton, J. (2007). The roles of quality and intermediary constructs in determining festival attendees' behavioral intention. Journal of Travel Research, 45(4), 402-412.

Liljander, V., \& Mattsson, J. (2002). Impact of customer preconsumption mood on the evaluation of employee behavior in service encounters. Psychology \& Marketing, 19(10), 837-860.

Liu, Y., \& Jang, S. S. (2009). Perceptions of Chinese restaurants in the US: what affects customer satisfaction and behavioral intentions? International Journal of Hospitality Management, 28(3), 338-348.

Loureiro, S. M. C., \& Kastenholz, E. (2011). Corporate reputation, satisfaction, delight, and loyalty towards rural lodging units in Portugal. International Journal of Hospitality Management, 30(3), 575-583. 
Malhotra, N. K., Kim, S. S., \& Agarwal, J. (2004). Internet users' information privacy concerns (IUIPC): The construct, the scale, and a causal model. Information Systems Research, 15(4), 336-355.

Malthouse, E. C., Oakley, J. L., Calder, B. J., \& Iacobucci, D. (2004). Customer satisfaction across organizational units. Journal of Service Research, 6(3), 231-242.

Nunnally, J. C., \& Bernstein, I. H. (1994). Psychological theory.

Pallant, J. (2005). SPSS survival manual. Berkshire.

Parasuraman, A., Zeithaml, V. A., \& Berry, L. L. (1988). Servqual: A multiple-item scale for measuring consumer perc. Journal of Retailing, 64(1), 12.

Prayag, G., \& Ryan, C. (2012). Antecedents of tourists' loyalty to Mauritius: The role and influence of destination image, place attachment, personal involvement, and satisfaction. Journal of Travel Research, 51(3), 342-356.

Sheils, O. M., \& Sweeney, E. C. (1999). TSH receptor status of thyroid neoplasms-TaqMan RT-PCR analysis of archival material. The Journal of Pathology, 188(1), 87-92.

Söderlund, M., Vilgon, M., \& Gunnarsson, J. (2001). Predicting purchasing behavior on business-to-business markets. European Journal of Marketing, 35(1/2), 168-181.

Su, C. H., Ryu, D., Young, R. I., Western, A. W., \& Wagner, W. (2013). Inter-comparison of microwave satellite soil moisture retrievals over the Murrumbidgee Basin, southeast Australia. Remote Sensing of Environment, 134, 1-11.

Taylor, S. A., \& Baker, T. L. (1994). An assessment of the relationship between service quality and customer satisfaction in the formation of consumers' purchase intentions. Journal of retailing, 70(2), 163-178.

Tepeci, M. (1999). Increasing brand loyalty in the hospitality industry. International Journal of Contemporary Hospitality Management, 11(5), 223-230.

Zeithaml, V. A. (1988). Consumer perceptions of price, quality, and value: a means-end model and synthesis of evidence. Journal of Marketing, 52(3), 2-22.

Zeithaml, V. A., Berry, L. L., \& Parasuraman, A. (1996). The behavioral consequences of service quality. Journal of marketing, 60(2), 31-46.

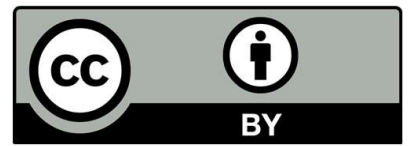

(C) 2020 by the authors; licensee Growing Science, Canada. This is an open access article distributed under the terms and conditions of the Creative Commons Attribution (CCBY) license (http://creativecommons.org/licenses/by/4.0/). 